\title{
Some considerations about the ecology of Triatominae
}

\author{
FRANÇOIS NOIREAU ${ }^{1,2}$, ANA L. CARBAJAL-DE-LA-FUENTE ${ }^{1}$, \\ CATARINA M. LOPES ${ }^{1}$ and LILEIA DIOTAIUTI ${ }^{3}$ \\ ${ }^{1}$ Departamento de Entomologia, Instituto Oswaldo Cruz, FIOCRUZ \\ Avenida Brasil, 4365, 21045-900 Rio de Janeiro, RJ, Brasil \\ ${ }^{2}$ UR 016, Institut de Recherche pour le Développement (IRD) \\ 911 avenue Agropolis, 34394 Montpellier, France \\ ${ }^{3}$ Laboratório de Triatomíneos e Epidemiologia da Doença de Chagas \\ Centro de Pesquisas René Rachou, FIOCRUZ, Avenida Augusto de Lima, 1715 \\ 30190-002 Belo Horizonte, MG, Brasil \\ Manuscript received on March 3, 2005; accepted for publication on March 30, 2005; \\ presented by Lucia Mendonça Previato
}

\begin{abstract}
Observations on the ecology of silvatic Triatominae are still fragmentary, principally because target species in control process are almost exclusively domestic. Report of silvatic species invading human dwellings must lead research to be focused on their original ecology, in order to assist in understanding their process of domestication and devising strategies for surveillance.
\end{abstract}

Key words: Chagas disease, Triatominae, silvatic environment, ecology.

\section{INTRODUCTION}

Chagas disease is ranked as one of the most important parasitic diseases in Central and South America in terms of social and economic impact (Schofield 1994). When in the early 1990s more than 16 million people were infected, control interventions successfully pursued in wide areas of Latin American are estimated to have reduced incidence of Chagas disease in Southern Cone countries by $60 \%$ in Paraguay and by up to $99 \%$ in Uruguay and Chile (WHO 1991, Dias et al. 2002, WHO/CTD 2004). The disease is caused by infection with the protozoan parasite Trypanosoma cruzi, mainly transmitted in the fecal droppings of infected insect vectors. These are

Dedicated to the memory of Prof. Dr. Herman Lent by initiative of Pedro L. Oliveira, Instituto de Bioquímica Médica. Universidade Federal do Rio de Janeiro (UFRJ), RJ, Brasil. Correspondence to: Dr. François Noireau E-mail: noireauf@ioc.fiocruz.br / noireau@mpl.ird.fr large blood-sucking bugs and form a subfamily of the Hemiptera named Triatominae. Their current classification is based mainly on the revision by Lent and Wygodzinsky (1979). According the more recent checklist of valid species, there are now 137 species placed in this Reduviid subfamily (Galvão et al. 2003). The great part of them is widespread in the Americas and maintains enzootic cycle involving wild mammals in a variety of biotopes. According to Rodriguero and Gorla (2004), the species richness of the New World Triatominae increases from the poles towards the equator, peaking over the $5^{\circ}-10^{\circ} \mathrm{S}$ latitudinal band.

Several triatomine species have adapted to human dwelling, becoming vectors of Chagas disease. Control of disease relies primarily on interruption of transmission by elimination of these domestic vector populations. Its expected success is aided 
by some basic characteristics of Triatominae that make them especially vulnerable to control interventions. They are slowly reproducing insects, with a low capacity of active dispersal, and they have a low population genetic variability. Particularly important is the almost exclusively domestic nature of target species as Rhodnius prolixus and Triatoma infestans (Schofield 1994), with the exception of restricted areas in the Bolivian Andes and Chaco where wild populations of $T$. infestans have been reported (Noireau et al. 2005). Finally, except the eggs, all stages are susceptible to insecticides. However, resistance to deltamethrin was recently detected in Argentinean field populations of T. infestans (Gonzalez Audino et al. 2004).

In many areas of Latin America, report of silvatic species invading synanthropic structures leads research to be focused on their natural ecology and role in the transmission to man of T. cruzi. Such researches still fragmentary must be expanded in order to assist in understanding the process of domestication and devising strategies for surveillance.

\section{THE SYNANTHROPIC TRENDS}

According to their epidemiological importance, the triatomines may be classified depending on their grade of association with man (Dias and Diotaiuti 1998). The species defined as primary ( $R$. prolixus and $T$. infestans) are colonizing permanently the human dwelling, usually in high density, are clearly anthropophilic and present significant index of natural T. cruzi infection. Besides the primary vectors, many other triatomine species are displaying synanthropic trends. According to the expanse of their area of distribution, their potential for colonizing human dwelling and proved vectorial capacity, these originally wild species are denominated secondary species, such as Triatoma brasiliensis and Panstrongylus megistus, or vector candidates as Triatoma sordida and Triatoma pseudomaculata. The secondary species are generally autochthonous of the region and capable of invading and colonizing the houses in the absence of a primary species (Dias and Diotaiuti 1998). Being native and ubiquitous, they occupy generally natural or artificial ecotopes close to the houses, are associated to wild or peridomestic animals and exhibit different grades of anthropophily. In particular situations, they can constitute large colonies inside the houses. Lastly, they are proved vectors in the transmission to man of T. cruzi. The vector candidates invade the peridomestic structures but are not capable of colonizing the human dwelling. Generally, the question of whether or not they can transmit $T$. cruzi to man is not resolved (Noireau et al. 1999). Although anthropogenic environmental changes and succeeding damage to triatomine biotopes seem to promote dispersion and favor the synanthropic process of silvatic species, the basic mechanisms of adaptation of the insect to artificial ecotopes remain poorly understood. Finally, traditional control approaches involving household insecticide spraying are unlikely to be effective against these vectors that keep a silvatic habitat.

According to the occurring of a previous infestation by a primary species and its subsequent eradication, the process of domestication of a wild triatomine may be regarded as primary or secondary (Noireau et al. 1999). It is primary when occurs without any relation to a previous eradication of a primary vector, and secondary when silvatic insects take the place of domestic vectors (Forattini et al. 1984, Noireau et al. 1996). The ecological succession following the control of the domestic population may be due to wild triatomines pertaining to the same species, as it is the case of Triatoma dimidiata in Central America and some areas of Colombia, Ecuador and Northern Peru (Dumonteil et al. 2004). More commonly, it is due to other triatomine species until now restricted to silvatic environment (Forattini et al. 1984, Dias 1988).

\section{COLLECTING METHODS}

Observations on the distribution, ecology and behavior of triatomine silvatic population (as its association to a specific habitat, nutritional status, feed- 
ing preferences, ability to complete the blood meal, dispersal ability and other behavioral features) are fundamental. They supply a "baseline behavioral pattern" of the species, for comparison purposes when further studies will be performed on other populations (for instance, populations displaying synanthropic behavior). Nevertheless, such studies about the wild ecology of triatomine species are still fragmentary, principally because collection of specimens and field observations are considered to be laborious and time-consuming.

The detection of triatomines in natural environment, necessary precondition for further studies, has recently benefited from the use of a simple trapping system (Noireau et al. 2002). For some species, this live-baited adhesive trap may provides the way to detect the presence of triatomines in various terrestrial and arboreal habitats (rock pile, hollow tree, palm tree...) and avoids the ecological damages caused, for example, by felling and dissection trees. Because only the starved bugs are attracted and captured, this system does not allow an estimating of the accurate density of insects and the population structure. Various lines of research are explored to improve the performance of the trap in the field and to design a new trapping system to be used for entomological vigilance after control interventions in intra- and peridomestic habitat. The efficiency of detection methods would benefit particularly from the use of chemical attractants, which would make traps easier to handle in the field and could help to reduce their size (Guerenstein and Guerin 2001).

\section{SILVATIC HABITAT AND SPREAD}

According to Gaunt and Miles (2000), links between the three most epidemiological important triatomine genera and sort of habitat do exist. So, species of the genus Rhodnius are primarily associated with palm tree, the genus Panstrongylus is predominantly found within burrows and tree cavities, and the genus Triatoma is associated with terrestrial rocky habitats or rodent burrows. If these assumptions are probably true for the genera Rhodnius and Panstrongylus, they are more questionable for the genus Triatoma. So, some Triatoma species may be exclusively found in hollow trees and/or bird nests (T. maculata, T. platensis, T. delpontei) when others exhibit a clear preference for rocks or caves.

Species may display a close relationship with one ecotope (Rhodnius brethesi with the palm tree Leopoldina piassaba, Psammolestes species with nests of Furnariidae) when others exhibit a greater range of ecotopes (Panstrongylus megistus, Triatoma dimidiata). Particularly interesting is the case of some triatomine species that can be found in arboreal as well as rocky habitat, when the great majority of Triatominae do not exhibit this feature. It is the case of T. infestans and T. sordida whose populations of altitude live in rock-piles when those of lowland live in trees. Such species provide good models for studying the pressure of habitat on morphology, genetic traits and behavior of triatomines. The current theory suggests the occurrence of rapid morphological divergence in response to different ecological factors (Dujardin et al. 1999). Indeed, we can observe obvious chromatic differences between arboreal T. infestans (melanosoma and dark morph populations; Martinez et al. 1987, Noireau et al. 2000) and terrestrial specimens collected in rocky habitat in Bolivia (clear morphs similar to domestic insects). Nevertheless, this model cannot be generalized. So, arboreal and terrestrial wild T. sordida do not display chromatic differences. Similarly, the genetically closely related species $T$. pseudomaculata and T. arthurneivai, that are probably issued from a common ancestor and have undergo an ecological divergence (the first species is arboreal when the second is terrestrial), do not exhibit significant morphological differences.

The current spread of some target species to free areas is worrying. It is, for example, the case of T. infestans that is spreading to warmer and humid areas in Bolivia (Noireau et al. 1996). The implementation of a landscape ecological approach and the applying of a spatial analysis using tools such as remote sensing and GIS can greatly enhance our ability to predict the spatial current distribution of 
target species (silvatic foci as well as peridomestic/domestic populations) but also their conceivable future expansion (Gorla 2002, Graham et al. 2004).

\section{SURVIVAL STRATEGY IN WILD TRIATOMINES}

The environmental disturbance brought about by man and succeeding damage of triatomine biotopes result in a condition of chronic distress in wild triatomine populations. This was clearly demonstrated in T. pseudomaculata in Northeastern Brazil where the silvatic insects exhibit a great weight deficit in relation to peridomiciliary ones. This adverse condition, that may lead the insect to apply a survival strategy related to the election of habitat, breeding behavior and host preference, is certainly the main cause of flight dispersal and subsequent settlement in artificial structures.

T. pseudomaculata lives in the caatinga of Northeastern Brazil and is strictly arboricolous. It can be collected in hollows of numerous tree species, amongst which locally predominant species such as Caesalpinia pyramidalis (caatingueira) and Auxemma oncocalyx (pau branco). In the framework of its survival strategy, this vector does not exhibit a restricted association with one (or some) tree species. But it is also found in nests of Furnariidae (Pseudoseisura cristata) and, more occasionally in burrows of Dasypodidae (Dias-Lima et al. 2003). In our study area in Bahia State, more than $50 \%$ of dissected trees were positive for T. pseudomaculata. The positive trees held small colonies of insects, rarely exceeding 10 individuals. It may suggest that females would lay a small quantity of eggs in a large number of ecotopes for increasing their chance of survival.

With relation to host preference, recent works have pointed out the occurrence of alternative feeding behavior in natural populations of Triatominae. So, we observed wild T. pseudomaculata, T. sordida, T. brasiliensis and Psammolestes tertius populations of the caatinga frequently feeding hemolymph of invertebrate (Carbajal de la Fuente et al. unpublished data). More surprising, a colony of Belminus her- reri collected from human dwellings in Colombia exhibited also a strong propensity to hemolymphagy (Sandoval et al. 2004). The importance and consequences of this biological trait are still unknown. Its occurrence might vary following the triatomine species but, at the level of the species, would be influenced by environmental conditions (accessibility to blood source). If fixed discrepancies were observed between species or groups of species, this behavior might help to better understand the evolutionary background of Triatominae. Relationships between hemolymphagy and population dynamics, and vector-T. cruzi interaction, might be contemplated.

This habit is derived from the predaceous behavior in other Reduviidae. Nevertheless, when the assassin bugs prey upon arthropods, pre-digest their tissues and kill their prey, the Triatominae seem only to immobilize their prey and suck their fluids in the process of hemolymphagy.

\section{PERIDOMESTIC POPULATIONS}

The survey of peridomestic populations and the question of their control are actually among the more difficult challenges. Some important questions remain about the understanding of domestic ecology of triatomines. So, T. brasiliensis and T. pseudomaculata are closely restricted to different ecotopes in wild environment (rock-piles and arboreal habitat, respectively; Dias-Lima et al. 2003). On the other hand, synanthropic populations of the same species give up this specificity. They compete for colonizing man-made structures and succeed in sharing the same substrates as wood and baked clay (Carbajal de la Fuente et al. unpublished data). The role of peridomestic structures remains misunderstood when occurs recolonization of insecticide treated villages. They may be source of reinfestation by residual populations, but also the earliest fixation point of insects coming from the silvatic environment (Diotaiuti et al. 2000, Gurtler et al. 2004). The estimating of gene flow between silvatic, peridomestic and domestic populations is a priority for under- 
standing and preventing reinfestation of insecticide treated houses.

\section{CONCLUSION}

When recent Chagas disease control activities are making substantial progress, the knowledge about silvatic triatomines, and particularly those in synanthropic process, is clearly insufficient. So, it took us one century after the discovery of Carlos Chagas to realize that triatomines, considered as obligated blood-sucking insects, could have with the hemolymphagy a common alternative feeding behavior. The recent advances of knowledge in the field of nutritional status and feeding habits might devise a means to distinguish silvatic bug populations in terms of their susceptibility to migrate. Combined with studies on orientation mechanisms and dispersal activity, they would greatly assist in understanding the process of domestication.

\section{RESUMO}

As informações sobre a ecologia de Triatominae silvestres são ainda incompletas, sobretudo porque as espécies mais importantes, alvos dos programas de controle, são exclusivamente domésticas. Registros de espécies silvestres invadindo as habitações humanas devem ser investigados para ampliação do conhecimento de sua ecologia no ambiente natural, de modo que se possa compreender melhor o processo de domiciliação e se criar novas estratégias para vigilância.

Palavras-chave: doença de Chagas, Triatominae, ambiente silvestre, ecologia.

\section{REFERENCES}

DiAs JCP. 1988. Controle de vetores da doença de Chagas no Brasil e risco de reinvasão domiciliar por vetores secundários. Mem Inst Oswaldo Cruz 83: 387-391.

Dias JCP And Diotaiuti L. 1998. Vectores secundarios de la enfermedad de Chagas en el Brasil y perspectivas para su control. In: GuHL F AND JARAMILlo CA (Eds), Curso Taller. Control de Tripanosomiasis Americana y Leishmaniosis: Aspectos Biológicos, Genéticos y Moleculares. Corcas Editores Ltda, Santafé de Bogotá, DC, Colombia, p. 154-159.
Dias JCP, Silveira AC And Schofield CJ. 2002. The impact of Chagas disease control in Latin América. A review. Mem Inst Oswaldo Cruz 97: 603-612.

Dias-Lima AG, Menezes D, Sherlock I and Noireau F. 2003. Wild habitat and related fauna of Panstrongylus lutzi (Reduviidae, Triatominae). J Med Entomol 40: 989-990.

Diotaiuti L, Faria Filho OF, Carneiro FCF, Dias JCD, Pires HHR AND Schofield CJ. 2000. Aspectos operacionais do controle do Triatoma brasiliensis. Cad Saude Publ 16 (Suppl. 2): 61-67.

Dujardin JP, PAnzera P And Schofield CJ. 1999. Triatominae as a model of morphological plasticity under ecological pressure. Mem Inst Oswaldo Cruz 94 (Suppl. I): 223-228.

Dumonteil E, Ruiz-Piña H, Rodriguez-Felix E, Barrera-Perez M, Ramirez-Sierra MJ, RabinoVICH JE AND MENU F. 2004. Re-infestation of houses by Triatoma dimidiata after intra-domicile insecticide application in the Yucatan Peninsula, Mexico. Mem Inst Oswaldo Cruz 99: 253-256.

Forattini OP, Rabello EX, Ferreira OA, Rocha E Silva EO AND SANTOS JLF. 1984. Aspectos ecológicos da tripanossomíase americana. XXI. Comportamento de espécies triatomíneas silvestres na reinfestação do intra e peridomicilio. Rev Saúde Pub 18: 185-208.

Galvão C, Carcavallo R, Rocha DS and Jurberg J. 2003. A checklist of the current valid species of the subfamily Triatominae Jeannel, 1919 (Hemiptera, Reduviidae) and their geographical distribution, with nomenclature and taxonomic notes. Zootaxa 202: 1-36.

Gaunt M And Miles M. 2000. The ecotopes and evolution of triatomine bugs (Triatominae) and their associated trypanosomes. Mem Inst Oswaldo Cruz 95: $557-565$.

Gonzalez Audino P, Vassena C, Barrios S, Zerba E AND PiCOllo MI. 2004. Role of enhanced detoxication in a Deltamethrin-resistant population of Triatoma infestans (Hemiptera, Reduviidae) from Argentina. Mem Inst Oswaldo Cruz 99: 335-339.

GoRLA DE. 2002. Variables ambientales registradas por sensores remotos como indicadores de la distribución geográfica de Triatoma infestans (Heteroptera: Reduviidae). Ecol Austral 12: 117-127. 
Graham AJ, Atkinson PM And Danson FM. 2004. Spatial analysis for epidemiology. Acta Trop 91: 219-225.

Guerenstein PG And Guerin PM. 2001. Olfactory and behavioural responses of the blood-sucking bug Triatoma infestans to odours of vertebrate hosts. J Exp Biol 204: 585-597.

Gurtler Re, Canale DM, Spillmann C, Stariolo R, Salomon OD, Blanco S and Segura EL. 2004. Effectiveness of residual spraying of peridomestic ecotopes with deltamethrin and permethrin on Triatoma infestans in rural western Argentina: a distinctwide ransomized trial. Bull World Health Org 82 : 196-205.

Lent H AND Wygodzinsky P. 1979. Revision of the Triatominae (Hemiptera, Reduviidae), and their significance as vectors of Chagas disease. Bull Am Mus Nat History 163: 127-520.

Martinez A, Olmedo RA and Carcavallo RU. 1987. Una nueva subespecie argentina de Triatoma infestans. Chagas 4: 479-480.

Noireau F, Breniere F, Cardozo L, Bosseno MF, Vargas F, Peredo C and Medinacelli M. 1996. Current spread of Triatoma infestans at the expense of Triatoma sordida in Bolivia. Mem Inst Oswaldo Cruz 91: 271-272.

Noireau F, Flores R, Gutierrez T, Vargas F, BreNIERE F AND Dujardin JP. 1999. Triatominae en Bolivia: importancia actual de los candidatos vectores. In: Alfred Cassab J eT AL. (Eds), La Enfermedad de Chagas en Bolivia - Conocimientos científicos al inicio del Programa de Control (1998-2002), La Paz: Ministerio de Salud y Previsión Social, OMS/OPS, IRD, IBBA, p. 127-133.
Noireau F, Bastrenta B, Catalá S, Dujardin JP, Panzera F, Torres M, Perez R, Galvão C and Jurberg J. 2000. Silvatic population of Triatoma infestans from the Bolivian Chaco: from field collection to characterization. Mem Inst Oswaldo Cruz 95 (Suppl. 1): 119-122.

NoIreau F ET AL. 2002. Trapping Triatominae in silvatic habitats. Mem Inst Oswaldo Cruz 97: 61-63.

Noireau F, Rojas Cortez MG, Monteiro F, Jansen AM AND Torrico F. 2005. Can wild Triatoma infestans foci in Bolivia jeopardize Chagas disease control efforts? Trends Parasitol 21: 7-10.

RodRIGUero MS AND Gorla D. 2004. Latitudinal gradient in species richness of the New World Triatominae (Reduviidae). Global Ecol and Biogeogr 13: 75-84.

Sandoval CM, Duarte R, Gutierrez R, Rocha DS, Angulo VM, Esteban L, Reyes M, Jurberg J AND GALVÃo C. 2004. Feeding sources and natural infection of Belminus herreri (Hemiptera, Reduviidae, Triatominae) from dwellings in Cesar, Colombia. Mem Inst Oswaldo Cruz 99: 137-140.

Schofield CJ. 1994. Triatominae: biology and control. Eurocommunica Publications (Eds), West Sussex, UK, 76 p.

WHO. 1991. Control of Chagas disease. Technical Report Series no. 811, Geneva, 95 p.

WHO/CTD. 2004. Chagas. http: // www . who .int/ctd/ chagas / epidemio . htm. 